\title{
'Mind the Gap': Assessing Differences between Brazilian and Mainstream IR Journals in Methodological Approaches
}

\author{
Thales Carvalho* \\ João Paulo Nicolini Gabriel ${ }^{\star \star}$ \\ Dawisson Belém Lopes ${ }^{* \star *}$
}

\begin{abstract}
In this article, we assess the methodological approaches employed in articles published in Brazilian and global mainstream IR journals in order to observe the differences between the two. To this end, we compare the methodological tools applied in research articles published in the top two Brazilian journals (Revista Brasileira de Política Internacional and Contexto Internacional) vis-àvis two other top international influential mainstream publications (International Organization and World Politics), from the year 2009 to 2019. By undertaking a Systematic Literature Review, we surveyed a total of 955 articles. Our research concluded that Brazilian IR scholarship differs from the mainstream literature because (1) most articles do not mention the mobilized methods during their analyses, (2) the field of IR presents more non- and post-positivist approaches, and (3) contrary to the mainstream outlets, quantitative methods are rarely employed in Brazil.
\end{abstract}

Keywords: methodology; International Relations; Brazil; scholarly production; systematic literature review.

\section{Introduction}

Studies in International Relations (IR) have experienced many methodological debates over the years - some of them directly related to epistemological divides. Disputes between positivists and their critics, qualitative and quantitative perspectives, and divergent

\footnotetext{
* Federal University of Minas Gerais (UFMG), Belo Horizonte - MG, Brazil; thalesleo1@gmail.com. ORCiD 0000-0003-4410-1367.

** Federal University of Minas Gerais (UFMG), Belo Horizonte - MG, Brazil; joao_paulo_apd@hotmail.com. ORCiD 0000-0002-4239-3522.

*** Federal University of Minas Gerais (UFMG), Belo Horizonte - MG, Brazil; dawisson@ufmg.br. ORCiD 0000-0002-1949-1001.
} 
propositions about how to address the issue of research design were commonly observed in the last decades. They not only contributed to the scientific development of IR scholarship but also enabled the blossoming of a plural and broader research field (see Acharya and Buzan 2019; Alejandro 2019; Bilgin 2008; Eun 2019; Brecher 1999; Kristensen 2020). In other words, as Wæver (1998: 723) claimed, 'IR [the discipline] is quite different in different places'.

Although the field of knowledge became increasingly pluralistic, a mainstream of researchers consolidated its prominence as the central nodes in the IR scholarship web. We refer to mainstream as the most cited researchers, institutions, and journals around the world, a synonym for what other authors have called 'core' or 'US-leading scholarship'. Its components are known to be mostly placed in the United States, especially in the so-called 'Ivy League' (see Lohaus and Wemheuer-Vogelaar 2020; Tickner and Wæver 2009) and, to a lesser extent, in Europe - especially the United Kingdom (Wæver 1998; WemheuerVogelaar et al. 2016).

After entertaining several methodological debates, positivism predominates among these mainstream scholars. As their work aims to find causal patterns on international phenomena and eventually produce predictions, positivist approaches were perceived as a means to provide objective and valid inferences (Maliniak et al., 2011; Mearsheimer and Walt, 2013; Biersteker, 2009). Simultaneously, in other countries, different perspectives became more frequently observed and majorly published, allowing one to identify 'multiple IR scholarships' (Jorgensen et al. 2017; Lohaus and Wemheuer-Vogelaar 2020; Villa and Pimenta 2017; Alejandro 2019).

In considering these differences, the following puzzle remains to be solved: What is the place of Brazil's IR scholarship in methodological terms? Despite the scarcity of sources, the existing literature suggests that the body of Brazilian studies differs from that of the global mainstream. For instance, it rests mainly on historical-descriptive analyses, with little incorporation of positivist debates (Santos and Fonseca 2009; Casarões 2019; Vigevani, Thomaz and Leite 2016; Herz 2002; Schwether et al. 2019). A possible explanation therefor is the fact that IR scholarship in Brazil is mostly driven by the objective to understand the role of the country at the international system - in a higher level than the one observed in the mainstream ${ }^{1}$ (Jorgensen et al. 2017). So far, few works have traced the methodological development of this field in Brazil to produce systematic comparisons between what is used in and outside the country to understand the place of Brazilian literature vis-à-vis that of the world.

In this article, we expect to contribute in terms of filling this gap, by conducting a systematic comparison to answer the following question: How different is the Brazilian scholarship from the mainstream regarding methodological choices? To that end, we apply a Systematic Literature Review (SLR), surveying articles published in the two leading journals representing the mainstream field - International Organization and World Politics $^{2}$ - and the two top IR journals in Brazil - RBPI and Contexto Internacional - over the course of ten years, from 2009 to 2019. Our findings unveiled three core differences between methodological instruments employed in articles published in Brazilian and the leading mainstream peer-reviewed journals. Firstly, in Brazilian journals, most papers do 
not explicitly describe which methodological design was applied to the research they refer to. This finding validates Schwether et al.s (2019) argument about the non-incorporation of rigorous positivist research designs in the country.

Secondly, while qualitative historical-descriptive works prevail in Brazil, providing valuable descriptions about the role of the country in the international arena (and related issues), the 'new qualitative methodology' (Rezende 2017) seems to have been adopted at a similar pace as that of mainstream journals, when methodological tools are concerned. The same does not apply to quantitative tools related to the 'inferential adjustment'3, which predominated in mainstream publications and appeared only in one of the articles among the Brazilian outlets under assessment. Finally, we identified a considerable presence of non- and post-positivist approaches in Brazil, such as Discourse Analysis and Ethnography, as compared to the global mainstream production.

Before proceeding with this analysis, it is crucial to introduce one caveat. This paper does not assume mainstream values and practices to be a role-model for Brazilian IR studies. Our aims are not to convey any sort of normative advice nor to endorse the crystallization of a US-cognitive-primacy approach. It should be noted that we definitely do not have any normative intentions in our article.

In turn, our research simply intends to bring to light differences between a given repertoire of methods and techniques employed in Brazil in comparison with the ones more recurrently found among leading global journals in the field. At the same time, we acknowledge that there are other IR scholarships around the globe and welcome comparisons between these bodies of scholarship and the Brazilian corpus. Understanding the place of the Brazilian IR scholarship in the world is a necessary and unavoidable debate for those interested in discussing its future developments.

The article is organized as follows. In the first section, we discuss how different from the mainstream IR in Brazil is, comparing their origins and present state of the art, since Lohaus and Wemheuer-Vogelaar (2020) claimed that a full understanding of a scholarly production elsewhere required considering the context in which knowledge was produced. In the second section, we briefly introduce the most employed methods in the mainstream literature so as to draw a comparison with Brazilian studies. In the third section, we discuss the research design employed in this analysis. Lastly, in the fourth section, we present and discuss our results.

\section{International relations in Brazil and the world: two sides of the same field}

The institutionalization of IR as a field of study emerged at the beginning of the $20^{\text {th }}$ century. The two first departments of International Politics in the world were set up in 1919 and 1920 in the United Kingdom (Vigevani, Thomaz, and Leite 2016). World War I outcomes sparked academic interests in the field in the sense that scholars started to search for answers for the causes of wars (Cox 1981; Viotti and Kauppi 2012). Along the same century, scholars based in the United States, the United Kingdom, and to a lesser extent, in Western 
European countries introduced their perspectives on the field. Heavily based on advancements in Political Science, they organized the mainstream epistemological principles of the area (see Acharya 2014; Mignolo 2002; Wallerstein 1997).

Historical-descriptive approaches assumed elements from the Political Philosophy to support their theoretical frameworks in the beginning, i.e., realism and liberalism (Carr 1989; Morgenthau 1978; Angell 2002). In the mid-20 th century, an increasing sophistication emerged in qualitative studies, within an emerging debate on levels of analysis and variables to be included for international political analysis. At the same time, behavioralist approaches gained momentum in the IR mainstream scholarship, leading to the inclusion of quantitative approaches into the field (see Alden and Aran 2016; Faria 2012; Kubálková 2001; Waltz 1992; Deutsch and Singer 1964).

Meanwhile, in the Global South, the Brazilian IR scholarship had a late development, as was the case in the entire Third World (Mignolo 2002). Whereas aforementioned debates were taking place in the mainstream of the field, IR discussions occurred in the country only within limited circles, such as the Instituto Superior de Estudos Brasileiros (ISEB), the Instituto Brasileiro de Relações Internacionais (IBRI) and, of course, the Ministry of Foreign Affairs. According to Fonseca Jr. (1999), few scholars, religious leaders, journalists, attorneys, military officials, and diplomats engaged in debates of this sort. At the time, the first journal specialized in IR - Revista Brasileira de Política Internacional (RBPI) was launched in 1958 under the inspiration of international publications such as Chatham House's International Affairs and The Council on Foreign Relations' Foreign Affairs, while also maintaining close ties with the Brazilian Ministry of Foreign Affairs (Casarões 2019; Dulci 2013; Almeida 1998).

While having a journal for scholars to publish analysis on IR issues, Brazil lacked an academic department dedicated to the discipline of IR in universities. Researchers often graduated in other areas - such as History, Law, Economics, Geography, and Social Sciences. Also, most of them spent some time in foreign institutions, especially in Western Europe - like Hélio Jaguaribe, Fernando Henrique Cardoso, and Celso Furtado. Unlike the mainstream IR scholarship, which had its roots in Political Science, the Brazilian field emerged from a pluralistic background and was mostly rooted in the French historical-descriptive tradition, remounting to authors such as Pierre Renouvin and JeanBaptiste Duroselle (Vigevani, Thomaz, and Leite 2016; Barasuol and Silva 2016; Tickner 2009; Alejandro 2019).

The first two IR departments in Brazil were inaugurated in the 1970s and 1980s, respectively in Universidade de Brasília (UnB) and Pontifícia Universidade Católica do Rio de Janeiro - PUC-Rio (Lima 2013), and consequently strongly related to the institutionalization of the field. The latter founded Contexto Internacional, the second Brazilian academic journal on international political issues in 1985. During this process, there were very few changes in methodological approaches mobilized in IR investigations in the country. Historical-descriptive approaches remained predominant at least until the end of the $20^{\text {th }}$ century. Two hypotheses emerge to explain it, along with the acknlowledgment of the center-periphery division of labor (Mignolo 2002; Wallerstein 1997). The first regards 
the problems Brazilians tried to tackle, which differed from the causes of war and several different matters that related to international politics in the mainstream IR scholarship. Brazilians gave precedence to national foreign policy and South American affairs. The second hypothesis concerns the relative lack of trusted data for research work in the country, a feature one could possibly associate with the authoritarian regime in Brazil (Santos and Fonseca 2009; Herz 2002; Tickner 2009; Kristensen 2020).

Having other answers to provide, mainstream IR went through another round of methodological debates. The emergence of an array of agendas required new manners of investigation. While historical approaches remained relevant for some theoretical approaches, such as the English School (Bull 1966), different theoretical frameworks were born (e.g., Structural Realism, Complex Interdependence, Neoliberal Institutionalism, etc.). In that context, positivist lenses appeared increasingly prominent in the search for objective and generalizable inferences (Jackson and Nexon 2013; Kaplan 1966).

During the 1990s and 2000s, sociological and post-positivist theoretical and methodological frameworks became increasingly debated in the mainstream, as well as in the Global South, with the emergence and dissemination of sociological, critical, and de-/ post-colonial approaches (see Kristensen 2018; Lapid 1989; Wendt 1992) - despite the fact that positivist approaches remained the most employed ones (Biersteker 2009). Concurrently, in Brazil, the IR scholarship was in a key moment of consolidation. The re-democratization of the South American country occurred in conjunction with a renewed national engagement in international politics, followed by an increase in government funding for research, which sparked new investigations, representing an expansion in both the supply and demand for IR research. There were more and more answers to be provided and loads of data to be analyzed, with more resources to fund them (Herz 2002; Tickner 2009).

Some (not necessarily intended) consequences of this process were the growing number of undergraduate and graduate programs, respectively from 20 in 1999 to 94 in 2009, and from 2 in 2001 to 24 in 2020 (Barasuol and Silva 2016; Pereira and Belém Lopes 2020). The leading Brazilian IR journals also adopted international publication standards, such as changing their working language from Portuguese to English, inviting international reviewers to join the review process, and making use of international submission platforms (Alejandro 2019). Another relevant accomplishment was the inauguration of the Brazilian Association of IR Studies and Scholars (Associação Brasileira de Relações Internacionais) in 2005 (Vigevani, Thomaz and Leite 2016). Within this context, as illustrated by Alejandro (2019), different traditions enmeshed in the local scholarship, such as a French one (more concentrated at PUC-Rio) and an American quantitativism (especially found at the Instituto de Relações Internacionais - Universidade de São Paulo [IRI-USP]).

Even after all these developments, Brazilian IR scholarship maintained its pluralistic character. Taking a glance at faculty members in IR departments in the country, Barasuol and Silva (2016) noted that only $20.5 \%$ hold a Master's in the field. The others came from different areas, such as Political Science (20\%), History (14.5\%), and Economics (13\%). Likewise, it is also remarkable that Brazilian scholars have never reached a consensus 
about Brazil's Western-ness (Kristensen 2020). This combination of pluralism, the need to provide different answers, all contrasting views, and different trajectories seem to have reflected in the methodological and epistemological choices of IR scholars in the country, as can be observed in the following figures.

In Figure 1, we show that whereas in the United States and other important IR scholarships researchers tend to prefer positivist approaches, in Brazil there is a nearly equal distribution between epistemological choices. At the same time, by including other countries in the plot, we can perceive that this Brazilian pattern is not an exception, in a sense that positivism is not as accepted around the world as it is in the USA (see WemheuerVogelaar et al. 2016).

Figure 1. Epistemological choices in Brazil and the world

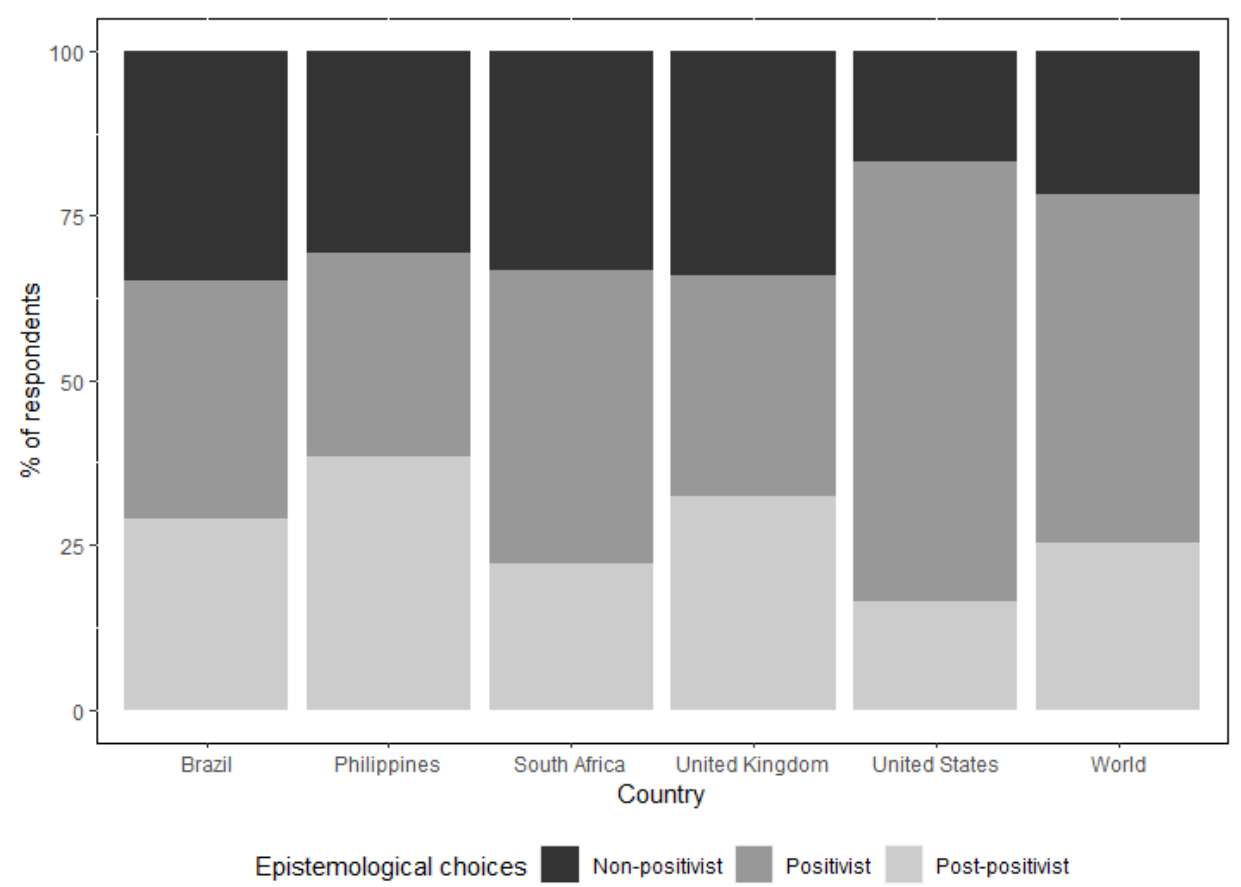

Source: Maliniak et al. 2017

Having epistemological perspectives other than the mainstream one seems to have driven Brazil away from the mainstream methodological choices, as shown in Figure 2. Brazilians are less prone to apply quantitative methods in comparison to their analyzed peers. If we consider that these tools are only employed by positivists, one would expect that by being less positivist, qualitative tools would predominate in the Brazilian IR scholarship. However, as Figure 2 also shows, Brazil once again is not alone in these preferences. Even some European scholarships, such as the French, present these methodological preferences. Still, the point is that the national IR scholarship differs from the mainstream, but not from the rest of the world. 
Figure 2. Primary methodological choices in Brazil and the world

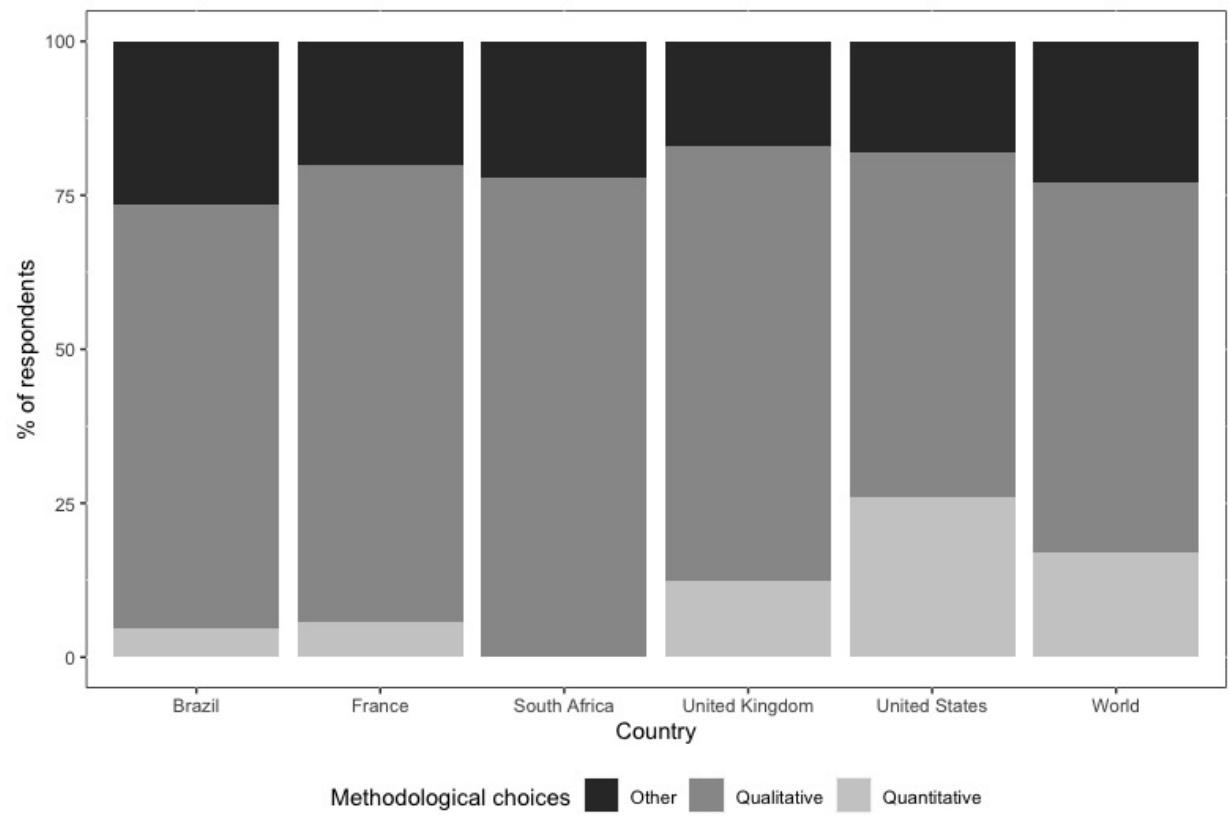

Source: Maliniak et al. 2017

Considering all of these differences, there is evidence that the Brazilian IR literature is somehow different from the mainstream regarding methodological issues. This was an expected outcome since this scholarship has a different trajectory and different problems to answer in comparison with the mainstream (Kristensen 2020). However, this discussion provided us with arguments to formulate two hypotheses to our research questions:

H1: Papers using qualitative methods represent a greater proportion of the total papers published in Brazilian journals than in mainstream publications.

As Brazilian researchers mostly prefer qualitative tools and especially considering that journals tend to display articles from scholars coming from the same geographical region (Lohaus and Wemheuer-Vogelaar 2020), an expected consequence is that Brazilian journals will mostly publish articles using these perspectives. Likewise, as mainstream researchers and publications are primarily based in the US - which presents a quantitative predominance in methodological approaches (Mearsheimer and Walt 2013; Sprinz and Wolinsky-Nahmias 2004; Maliniak et al. 2011), we can expect a more significant presence of quantitative investigations.

H2: Even considering the same kind of methodology (i.e., qualitative or quantitative), the methodological tools employed in papers published in Brazilian journals are different from the mainstream journals.

If methodological choices are supposed to be highly influenced by trajectories and the problems to be solved, then having different origins and puzzles, Brazilian and mainstream 
scholars will differ in the methods chosen for their analyses. Even when considering the same type of research, i.e., they will use different qualitative or quantitative methods. It is also important that contrasting trajectories may lead to different methodological training, translating it into distinct choices. Such a context observed in Brazil reflects the prevalence of different techniques vis-à-vis the mainstream ones.

But what techniques are we talking about? What will we search for while trying to answer these hypotheses? In the next section, we will answer these questions, clarifying what methods are being considered for this analysis.

\section{Methodological debates in the mainstream of IR}

As we are comparing how different the methodological tools mobilized in Brazilian IR publications compared to the mainstream ones are, it is crucial to report which are the most frequently applied instruments by the mainstream. We acknowledge the valuable role of other epistemological approaches, such as interpretivism and reflexivism, as well as their methods, such as Discourse Analysis and Ethnography [see, for example, Alejandro (2019; 2021), Lichterman (2017), and Montsion (2018)], and their role in Brazil. However, considering our aims, in this section we introduce only the most used mainstream techniques in order to clarify what we are comparing the methodological approaches employed in Brazilian journals to.

The mainstream IR scholarship, as mentioned, embraced positivistic lenses in a search for objective and replicable analyses on an increasing number of issues related to international politics. Whether looking at a small or large $n$, methodological debates have been leading to the emergence of a growing number of tools directly connected to developments in Political Science. In this context, quantitative instruments became the most utilized methods in the mainstream IR field (Mearsheimer and Walt 2013; Sprinz and Wolinsky-Nahmias 2004; Maliniak et al. 2011).

Experimental research has been increasingly published, as IR scholars are getting as close as possible to research designs employed in the natural sciences to search for the best objective causal inferences (see Imbens and Rubin 2015). Experiments are not so easy to do in IR, since we cannot randomly distribute the field's analyzed social phenomena, such as the occurrence of wars, and simply observe the outcomes. However, along with the possibility of laboratory and public opinion experiments, some elements in the international realm can be randomly assigned, such as electoral observers (Hyde 2007), making it possible to rely on experimental data.

Still, as experimental data is usually hard to obtain, researchers have been trying to replicate information which is closer to it, that is, quasi-experimental research designs. For example, it is possible to compare similar units in a set of control variables that differ only in the treatment variable. That is the foundation of 'Matching', one of the instruments that emerged from recent debates and has been increasingly applied in both Political Science and IR (Imbens and Rubin 2015; Morgan and Winship 2007).

Another widely used quantitative instrument is 'Panel Data Analysis'. For these models, it is also considered how cases behave along a time series, providing a rigorous control 
of unit and time trends - associated with relevant covariates (Imbens and Rubin 2015; Morgan and Winship 2007). The same authors also mentioned the role of approaches based on instrumental variables in situations in which there is endogeneity, considering dependent and independent variables. A two-stage regression could be a solution for these problems, using an instrument that is not correlated with the dependent variable. Also, depending on both variables and objectives, Cox Proportional Hazards can be a valuable method to produce inferences (Lins 2020). Matching, Panel Data Analysis, and Cox Proportional Hazards are all techniques to deal with what Rezende (2017) called the 'fundamental problem of the causal inference. That is, these methods joined traditional statistical tools, such as regressions and correlation tests, providing research designs that allow for robust and often unbiased inferences.

Likewise, there were also considerable advancements in qualitative approaches that sought increased objectivity and accuracy in inferences. Traditional methods, such as case studies and comparative analyses, were thickened by more rigorous strategies. Processtracing improved researchers' capacity to analyse causal connections by unpacking the mechanisms that produced them, being useful to either positivist and post-positivist scholars (Beach and Pedersen 2016; George and Bennett 2015). Comparative-historical analysis was refined to achieve more sophisticated results (Amorim Neto and Rodriguez 2016; Falleti and Mahoney 2015; Goerz and Mahoney 2012). These developments, which Rezende (2017) called the 'new qualitative methodology', have also been increasingly present in mainstream publications.

Another relevant aspect is the rise of multi-method approaches. Brecher (1999) discussed the importance of integrating both qualitative and quantitative methods towards multi-method analyses. Sprinz and Wolinksy-Nahmias (2004) show an increasing trend to adopt these designs in the 2000s. Scholars such as Brady and Collier (2004) also mentioned how these approaches would be promising for the Social Sciences as a whole, providing, at the same time, the capacity to generalize findings and detail cases and causal mechanisms. Therefore, while comparing Brazilian publications with mainstream ones, we intend to shed some light on the incorporation of the aforementioned methods in papers published by four outlets (Contexto Internacional, Revista Brasileira de Politica Internacional, International Organization, and World Politics).

\section{Research design}

We built an original dataset to describe the differences between the methodological strategies adopted in leading Brazilian and mainstream IR publications that were observed. Our sample contains all articles published in four IR journals (two Brazilian and two mainstream ones) from 2009 to 2019. To assess the 'best' IR articles in Brazil, two of the leading journals in the country, namely Revista Brasileira de Politica Internacional (RBPI) and Contexto Internacional ${ }^{4}$, were selected. As show in Figure $3^{5}$, despite RBPI's raising internationalization in the past decade, most papers published in both journals have at least one Brazilian-based author (in a few cases, we could see them coauthoring papers with 
researchers from other countries, as shown in the label "Brazilian and foreign"), making our sample representative of the Brazilian production. To account for the elite of the mainstream scholarship in the world, we selected the two best-ranked publications according to three main impact factor rankings ${ }^{6}$ dedicated to the general debate in IR issues ${ }^{7}$, namely International Organization (IO) and World Politics, to make up a representative duo.

Figure 3. Nationality of authors who published in Brazilian journals, based on their institutions of affiliation

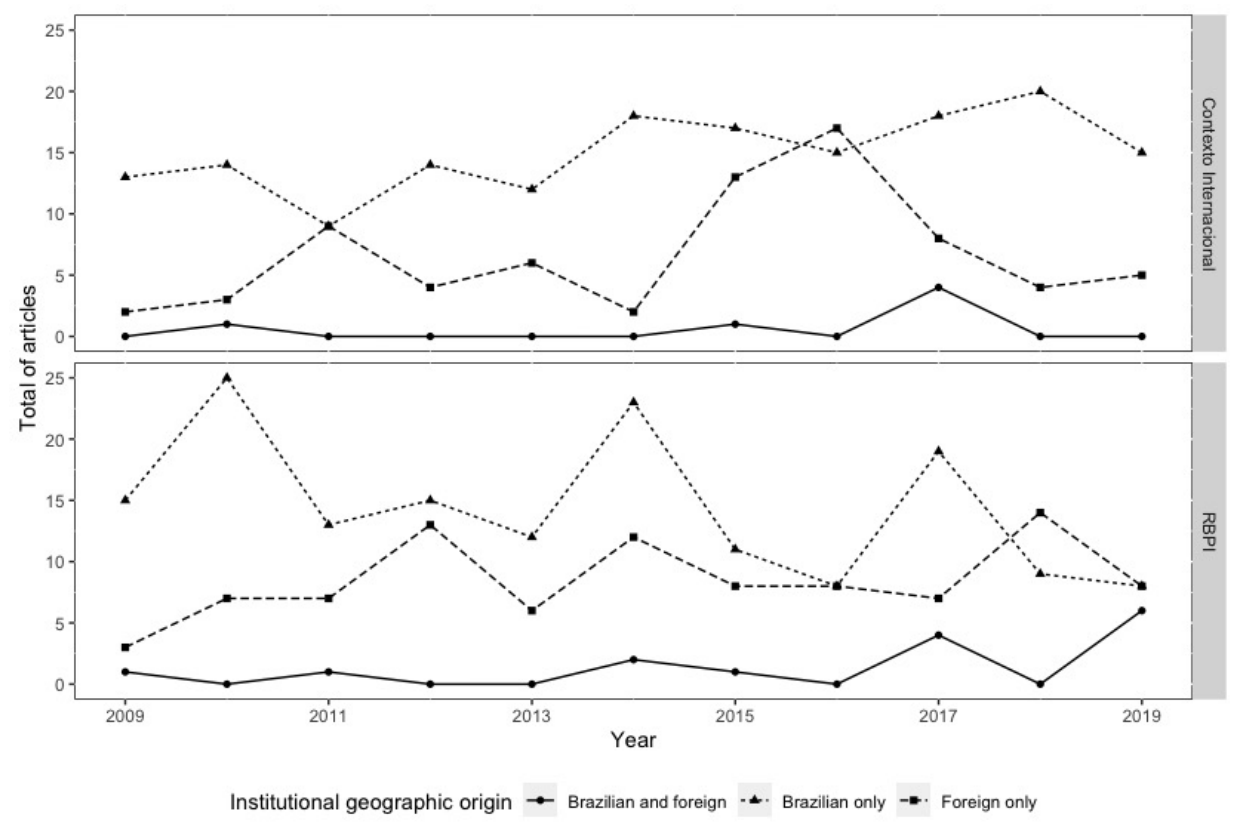

Source: Elaborated by the authors.

According to the editorial information available on the websites of the four journals, all of them are dedicated to surveying international phenomena. While three of them do not specify any geographic area of interest, Contexto Internacional mentions its focus on the Global South. Since all of them address several issues related to the international level of analysis and are not restricted to specific issues (e.g., international security, international political economy), we consider the four journals to be comparable. Table 1 corroborates our perception. We analysed the word frequency in the titles of each published paper in each journal. We can observe that all of them present a relatively high mention of the term 'international' ( $>20 \%$ of the total papers, with the exception of World Politics). Also, Brazilian journals tend to attribute a closer focus to Brazil, in a sense that the titles of published papers mentioned the country in $10.65 \%$ in Contexto and roughly one quarter in RBPI.

Regarding methodology, only World Politics makes clear that all methodological perspectives may be represented in their issues. However, as the others do not explicit which kind of methodology is preferable, we consider that there are no barriers 


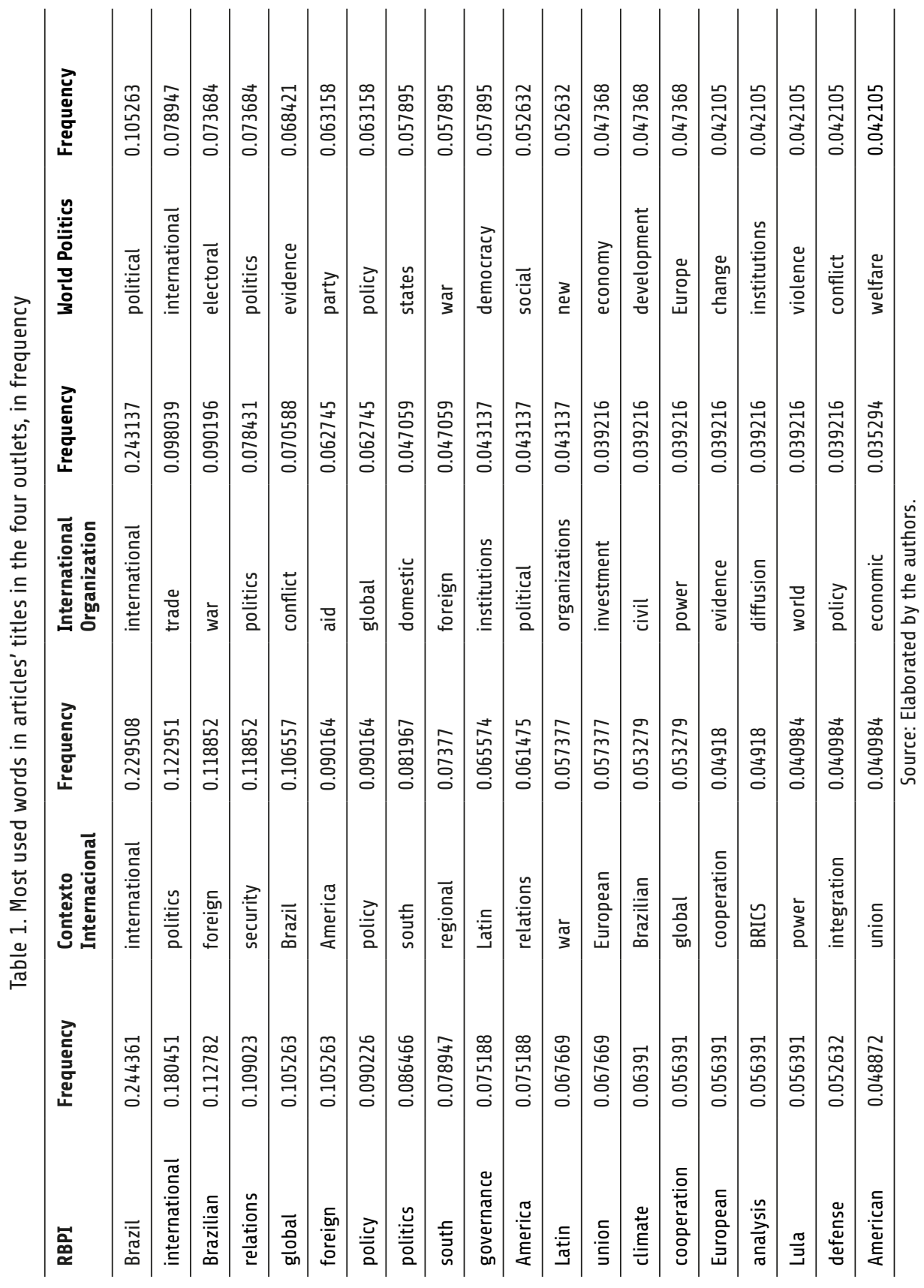


to any epistemological or methodological perspective ('Instructions for Authors' n.d.; 'Instructions for Authors' n.d.; 'Editorial Scope and Policy' n.d.; 'Scope and Policy' n.d.). This is not to say that there are no entrance barriers at all. We acknowledge, for example, gate-keeping practices, especially in mainstream journals, that may veto articles written in the Global South because of the different methodological choices or related factors (Alejandro 2019; Lohaus and Wemheuer-Vogelaar 2020). Still, since we want to compare Brazilian publications with mainstream ones, these practices are not within the scope of our analysis.

We have run a Systematic Literature Review (SLR) over this sample. We chose SLR first because it is a valuable tool to understand what has been said in the literature in a given period of time. Also, it consists of an objective and replicable method, providing scientific validity to our inferences (Parris and Peachey 2013; Ridley 2012). We analysed 955 articles, ${ }^{8}$ including their abstracts, introduction, and research designs (when applicable), in order to identify which methods were utilized in each one of them. We proceeded with such analysis with one caveat: This study does not intend to evaluate the articles' contents. Our analysis was based upon observing whether authors were explicit about which methods were applied to provide answers to their puzzles - or not. When they did, we included the mentioned tool in our database. When there was no mention of these tools, we identified them as not identifiable (n/a). As a strategy to make our judgments more reliable, two of us analysed each article.

As described in the last section, we considered just methodological tools adopted to analyse data. We did not include in our dataset techniques related to data collection or production, such as interviews, document analysis, and bibliographic review (except for the case of SLR). We reported criteria to code each paper as qualitative, quantitative or multi-method designs in Appendix A. We made this option because we want to compare how scholars are analysing, not gathering data. Then, we reported results in different variables. Firstly, the kind of data analyzed in each article - either observational or experimental. Secondly, the methods employed in each paper, allocated in different columns for qualitative and quantitative tools. Remarkably, since there are multi-method articles, the same paper can present different instruments - for instance, if authors reported they used case study and OLS regressions, we reported both methods at our database. Finally, there was a variable in which we reported the kind of methodology(ies) mobilized in scrutinized papers - either qualitative, quantitative, or both. Categories, in this case, were mutually excluding. In the next section, we report the results.

\section{Results}

This section will present and discuss the Systematic Literature Review results, aiming to demonstrate differences between articles published in Brazil and mainstream journals. Before approaching methodologies themselves, we noted the kind of data researchers had been using - specifically, if there was any trend towards employing experimental data/designs. This choice tended to precede methodological choices, since methods need to fit the 
analysed data. Hence, as can be seen in Figure 4, while experimental research designs have been increasingly utilized in the two mainstream publications, only one paper published in Brazil relied on this kind of technique. Three possible explanations therefor might be (1) the kinds of problems addressed by Brazilian researchers are not conducive to the technique, (2) the fact that experiments tend to be expensive, and (3) most researchers tend to perceive this kind of design as a wishful thinking, something impossible to implement in IR studies. Still, this is the first stark difference between the methods employed in the compared publications that have also something to say about trends in causal inference designs in the analysed journals.

Figure 4. Number of experimental research designs in each journal

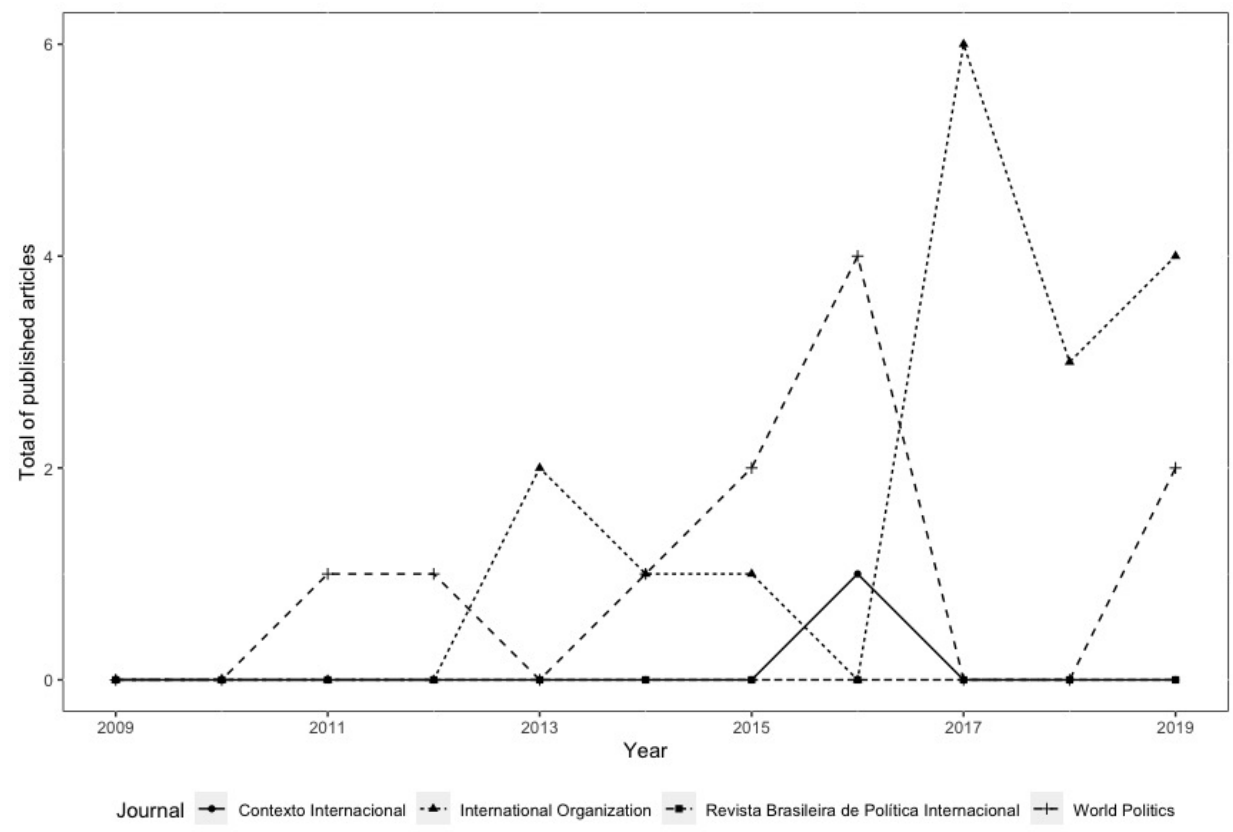

Source: Elaborated by the authors.

More than different kinds of data, articles published in Brazilian outlets adopt distinct methodologies, as shown in Figure 5 below. A significant proportion of papers used quantitative tools in mainstream journals, confirming what was discussed in the last section. Concurrently, these methods are not common in Brazilian journals. Only 15 out of 510 papers published in RBPI and Contexto Internacional display this kind of research design. There is also an increasing number of papers combining qualitative and quantitative approaches in mainstream journals, whereas no article applied this kind of approach in Brazil. 


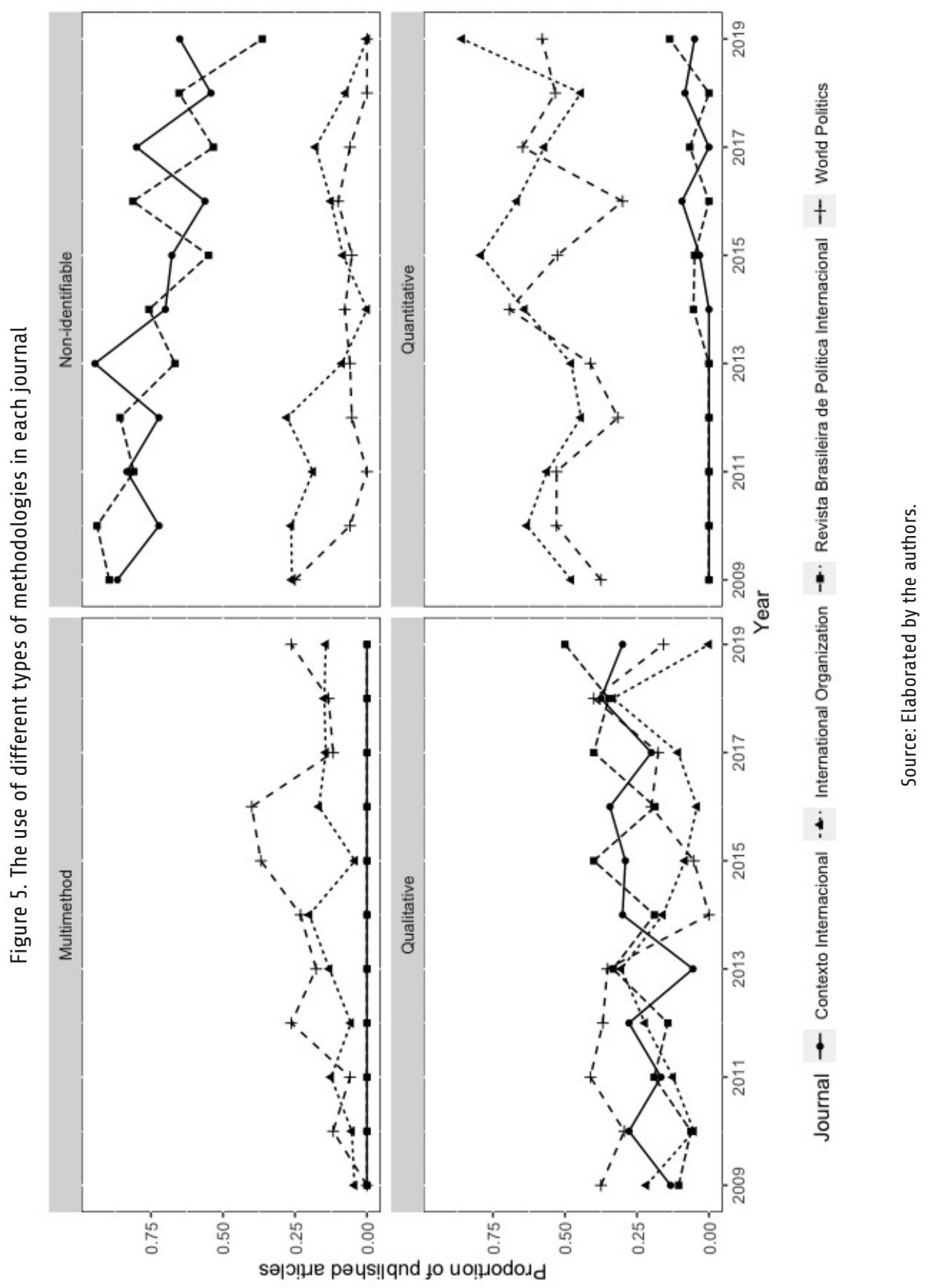


The gap between methodological approaches adopted in Brazil and mainstream journals is diminished when it comes to qualitative tools. The proportion of papers applying this kind of methodology is quite similar when comparing the two journal samples. This was an unexpected finding, firstly because papers published in Brazilian outlets adopt neither quantitative nor multimethod approaches, and also because of the qualitative tradition of the local IR scholarship (Vigevani, Thomaz, and Leite 2016; Herz 2002; Barasuol and Silva 2016).

The tentative explanation, however, is also found in Figure 5, that is, the fact that most published articles in Brazilian journals do not specifically identify their methodological choices. Except for RBPI 2019 issues, more than half of the articles in these outlets do not even mention which methodological tools they are using to analyse data. Most of them describe Brazilian foreign policy or the regional environment, meeting the historical-descriptive tradition in the country. However, the papers did not mention any methodology, such as historiography. Also, there is no mention of interpretivist or reflexivist methodologies in these works. In mainstream journals, a similar proportion of non-identifiable methodological choices for articles published only occurred in the 1970s (Sprinz and Wolinsky-Nahmias 2004).

However, it is also noteworthy that the proportion of articles that did not identify the employed methods have been decreasing since the year 2009, as shown in Figure 5. As indicated by Figure 6, this reduction seems to be related to two facts, namely (1) an increasing number of scholars who are not based in Brazil are publishing in the country using qualitative methods - especially in RBPI - and (2) Brazilian scholars have been reducing the number of articles they published without mentioning methodological tools, while also raising the number of papers that used either qualitative or quantitative approaches.

Still, we cannot corroborate $\mathrm{H} 1$ since qualitative methods did not represent a greater proportion of papers published in Brazil than in the mainstream publications. This proportion is actually similar. As all of the articles that did not mention methodological tools rely on a small $n$, our analysis only shows that these papers, focusing on a small number of cases, are more common in Brazil. Searching for a more specific diagnosis - and to test $\mathrm{H} 2$ - Figure 7 presents the proportion of specific qualitative methods while considering only articles that mobilized qualitative or multimethod designs. It is noteworthy that authors could have mentioned more than one tool in the same article, e.g. a case study that also used process-tracing. In these cases, both methods were reported.

For one, we can observe that qualitative papers published in IO tend to employ more case studies than the others, which in turn adopt a similar proportion of this instrument. The contrary happens when we look at comparative approaches. It is worth remembering that, in the case of mainstream publications, the use of qualitative methods is sometimes linked to qualitative tests in multimethod research. Still, while also looking at these indicators, it is not possible to conclude that there are differences between Brazilian and mainstream publications, since their results were very similar to those obtained from World Politics. 


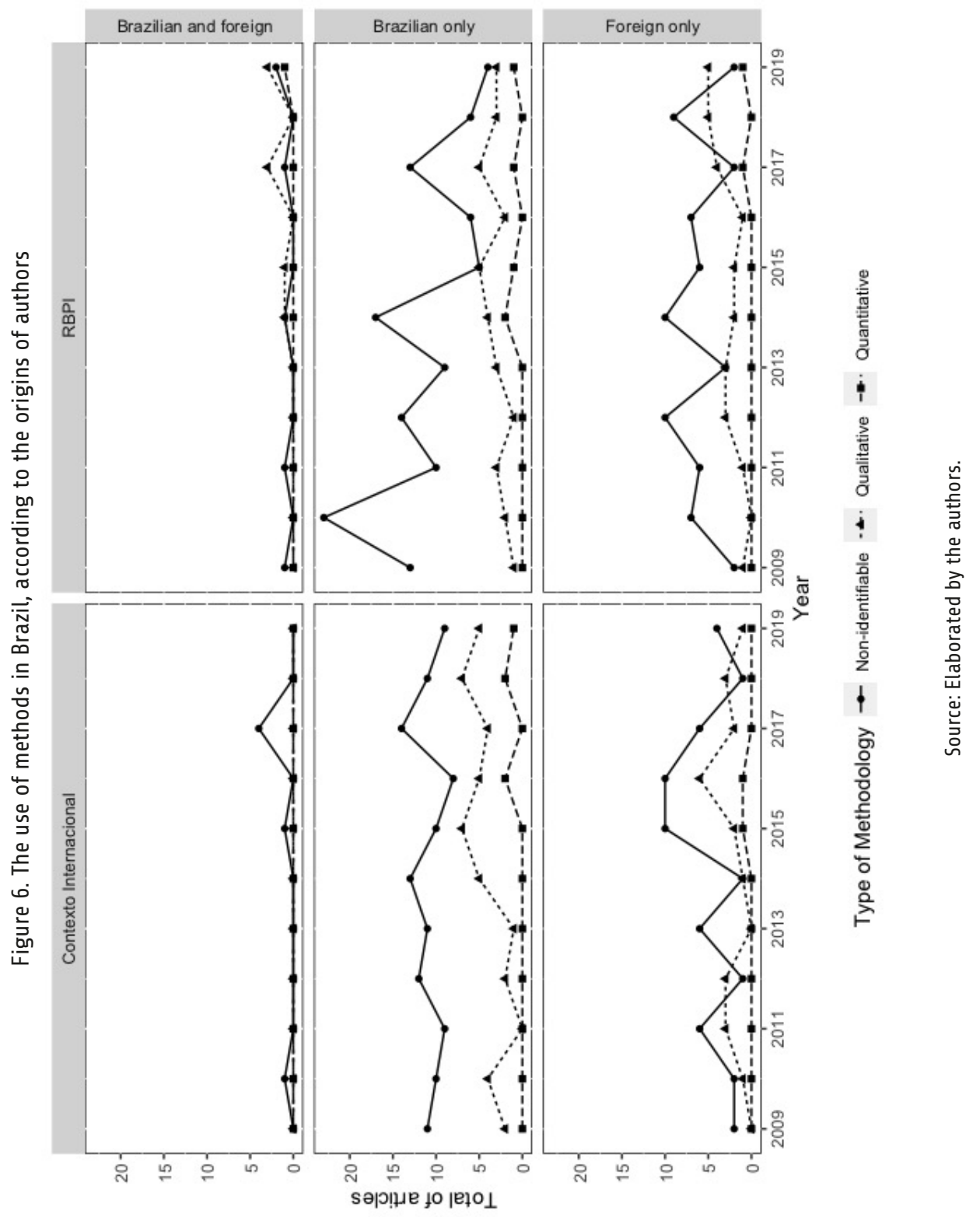


The other indicators, however, show these differences. Post-positivist methods, such as Discourse Analysis and, to some extent, Ethnography, are more present in Brazil than in mainstream outlets. This was expected, as the existing literature claimed that more Brazilian researchers assume non/post-positivist paradigms than mainstream scholars. Content analysis is relatively common in Brazil but also in International Organization, which leaves no margin to infer noticeable differences regarding this method.

When we look at the so-called 'new qualitative methodology', comparative historical analysis was neither common in mainstream publications nor in Brazil. This finding was unexpected since, as Amorim Neto and Rodriguez (2016) claimed, this is a valuable tool to explain political phenomena in Latin America. Conversely, process-tracing was similarly used in the four analyzed publications. Hence, it is possible to conclude that the incorporation of these methods is not so different in Brazil and the mainstream. In the end, the main difference regarding qualitative methods is that articles published in Brazil tend to adopt more post-positivist methods than mainstream journals.

However, a disclaimer should be introduced here: these results apply only to the comparison of articles that used qualitative methods. If we consider all the small-n analyses, thus including papers in which methodological tools are not identified, it is possible to claim that the incorporation of the 'new qualitative methodology' in Brazilian publications is indeed lower than in the mainstream.

Regarding quantitative methodology, in Figure $8^{9}$, we can see first that regressions [either Ordinary Least Squares (OLS), Logistic (Logit), or Probit] are highly employed in mainstream publications, but not in Brazil. The 'inferential adjustment' techniques have found some considerable space in foreign journals, but not yet in the Brazilian ones: no paper utilized Cox Proportional Hazards, Matching, or Two-Stage Regressions in the country. One of these techniques - Panel Data Analysis - is used in more than 50\% of the articles recently published in mainstream journals, while only one paper published in Brazil (in RBPI) employed this instrument. Therefore, this is another key difference between mainstream journals and the Brazilian ones, no matter how helpful 'inferential adjustment' techniques might prove to be for explaining several issues related to Latin America. 


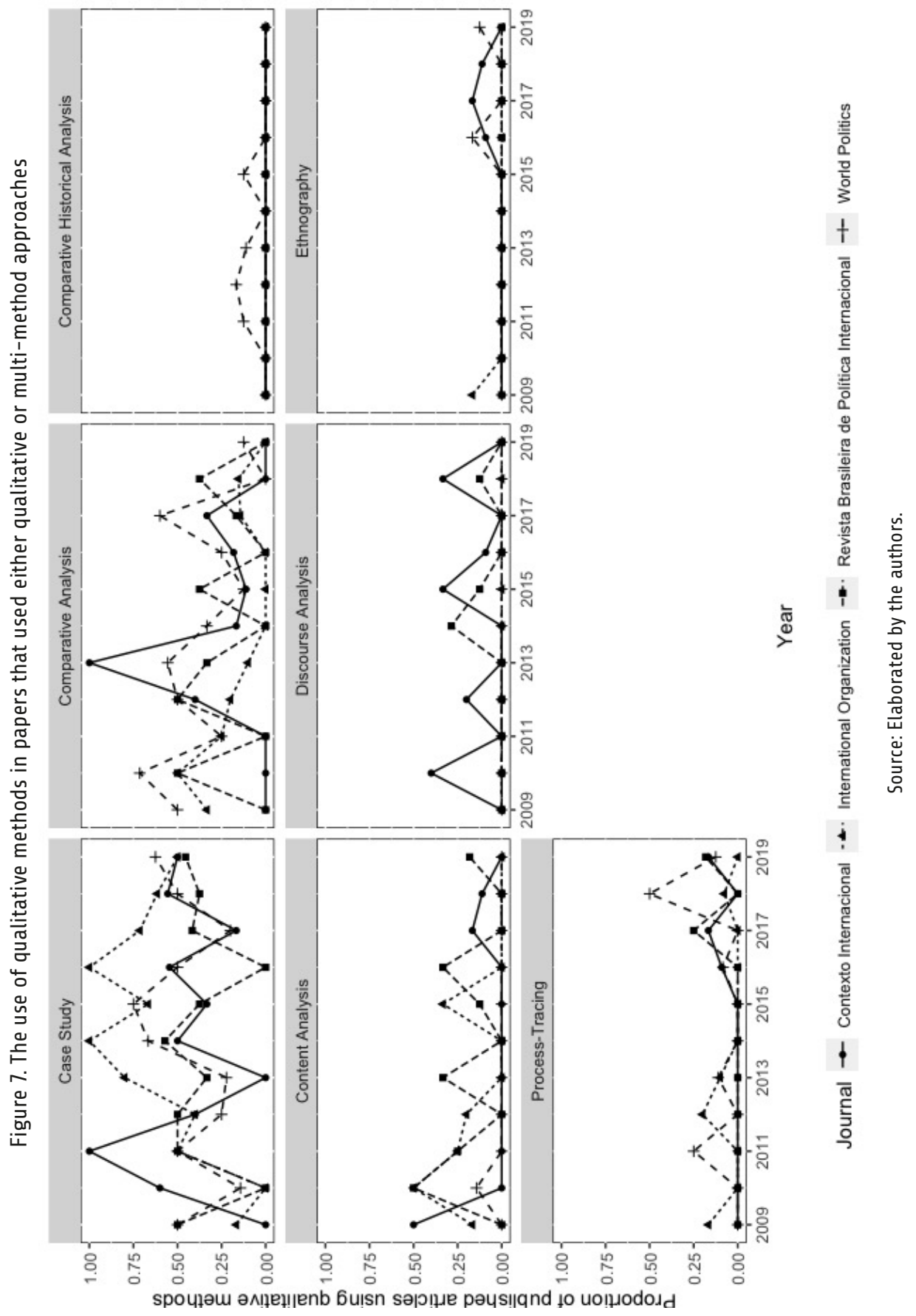




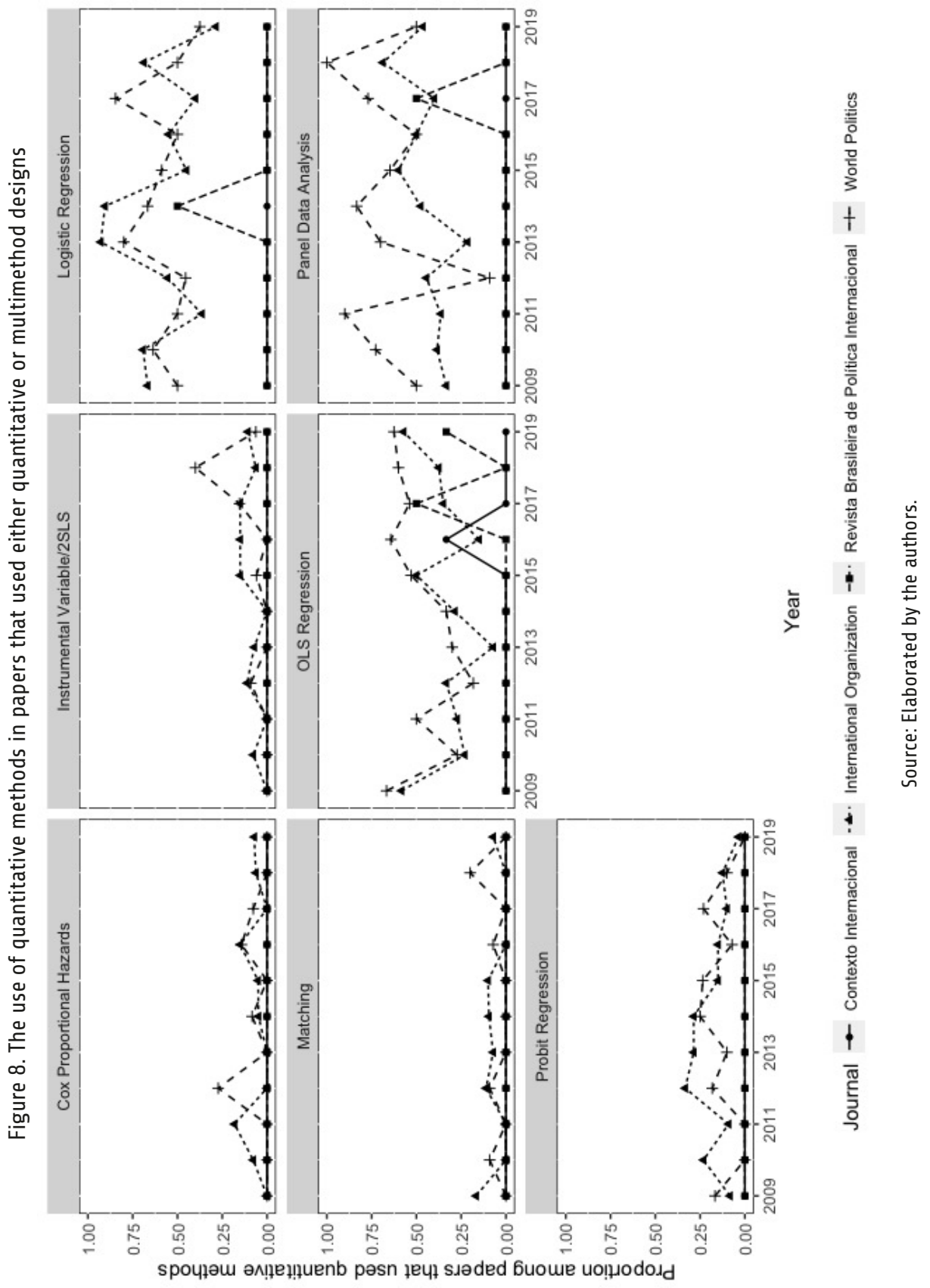


From the evidence presented in this section, it is possible to conclude that papers using qualitative methods do not represent a greater proportion of the total papers published in Brazil than they do in mainstream journals, contrary to what had been expected. What is possible to infer is: (1) articles that do not describe or mention methodological choices are more common in the country, as well as the occurrence of (2) small-n analyses. Therefore, our first hypothesis was rejected, but the final conclusion is not so distant from our point of departure.

Our second hypothesis was corroborated. When we look at the qualitative and quantitative tools separately, some differences are easily perceptible. In terms of qualitative techniques, Brazilian publications tend to present more post-positivist methods than the mainstream ones. Another interesting finding was that Brazilian and mainstream journals present similar degree of incorporation of the 'new qualitative methodology' - when they mention their qualitative tools. Finally, while International Organization and World Politics present more than half of their articles using 'inferential adjustment' techniques, RBPI and Contexto Internacional do not seem to incorporate them.

\section{Conclusion}

After undertaking a Systematic Literature Review in articles published in International Organization, World Politics, Contexto Internacional, and Revista Brasilera de Política Internacional, we observed some relevant differences between the methodological approaches adopted by Brazilian and mainstream IR journals. Firstly, the historical-descriptive tradition in local studies seems to prevail, probably because it has proven to be able to deal with some of the main problems that the national IR academy has to tackle, particularly the role of Brazil in its region and the world, as indicated in Box 1. Hence, several papers published in the country provide valuable descriptions while not clearly defining the methodological guidelines employed in the analysis. This is quite different from the mainstream publications, in which clarifying methodological design is a condition for having an article published.

The prominence of these articles made it impossible for us to conclude that qualitative methods are more widely used in Brazilian journals than in the mainstream ones. Likewise, it was possible to confirm that small-n analyses predominate in the country. Contrary to the IR mainstream, quantitative investigations are quite rare in Brazil, despite this being a useful path to provide a better understanding of the region. Finally, when we consider only qualitative articles, the ones from Brazil mobilize more post-positivist methods than the mainstream ones. The adoption of the 'new qualitative methodology' is similar between RBPI, Contexto, and World Politics, although this changes when we look at small-n articles, not only in pieces which mentioned/described qualitative methods. Regarding the 'inferential adjustment' techniques, while widely adopted in mainstream journals, they seem still incipient in the Brazilian ones.

Brazil seems to be developing a fertile ground for plural methodological perspectives, assimilating a combination of different traditions, thus looking very different from 
the mainstream; yet, this is not necessarily a new finding. The main contribution of this article is to identify 'how different' - to phrase it in a more neutral way - the Brazilian IR scholarship is from the discipline mainstream. We believe this article may contribute to the understanding of the Brazilian position vis-à-vis the global IR academy - or, at least, to provide a detailed report on the state of affairs. We hope this article encourages scholars to deepen on methodological agendas to deal with the puzzles that Brazilian analysts will have to solve in the coming years.

\section{Notes}

1 In the mainstream, authors are also obsessed, to some extent, by the role played by the United States. However, the mainstream develops theoretical approaches that attempt to convey their local knowledge, interests, and ideals throughout the world. In Brazil, scholars commonly focused both on regional issues and the role of Brazil.

2 Despite not being part of our criteria to choose the cases, it is worth noticing that these journals are currently published in the United Kingdom.

3 We call 'inferential adjustment' a set of techniques that emerged after King, Keohane and Verba's 'Designing Social Inquiry' (1994), aiming to improve causal inferences. It intensively uses formal modeling, quantitative methods (or multimethod research) and focuses on causal logic to produce inferences (Rezende 2017). Examples of techniques classified under the 'inferential adjustment' umbrella are Panel Data Analysis and Matching.

4 Both are mentioned as the two leading publications in Brazil in the literature cited in the last section. Also, this is corroborated by indexes provided by Scielo and Google Scholar.

5 For a better picture about authors' nationalities in foreign journals, see Lohaus and Wemheuer-Vogelaar (2020), and Noda (2020).

6 Google Scholar, SCImago (SJR), and Web of Science/Clarivate Analytics (JCR). In the case of the latter, as data are available for the period analysed in this article, we considered their classification on the past ten years in the ranking.

7 Journals such as International Security and Journal of Conflict Resolution were automatically excluded from the sample because of their focus on specific (security) issues.

8 Two hundred sixty-six (266) papers from RBPI, 244 from Contexto Internacional, 255 from International Organization, and 190 from World Politics. As we wanted to analyse methods, we excluded book reviews from the dataset. Also, as we wanted to analyse the most advanced papers from each journal, we focused only on research articles, also excluding research notes, in the case of the international publications.

9 When journals did not score anything in any method, it means that they did not publish any article using quantitative research designs that year, or published other non-presented methods, such as other kinds of regressions (e.g., quantile regression). To improve reader visualization and optimize space, we only presented results that referred to the most used methods.

\section{References}

Acharya, A. 2014. 'Global International Relations (IR) and Regional Worlds: A New Agenda for International Studies.' International Studies Quarterly (58):647-659. https://doi.org/10.1111/ isqu. 12171

Acharya, A and B Buzan. 2019. The Making of Global International Relations: Origins and Evolution of IR at its Centenary, 1st ed. City: Cambridge: Cambridge University Press. https://doi. org/10.1017/9781108647670 
Alden, C and A Aran. 2017. Foreign policy analysis: new approaches, Second edition. ed. London ; New York: Routledge, Taylor \& Francis Group.

Alejandro, A. 2021. 'Reflexive discourse analysis: A methodology for the practice of reflexivity' European Journal of International Relations (27):150-174. https://doi.org/10.1177/1354066120969789

Alejandro, A. 2019. Western dominance in international relations? the internationalisation of IR in Brazil and India, Worlding beyond the West. London; New York: Routledge.

Almeida, P R de. 1998. 'Revista Brasileira de Política Internacional: quatro décadas ao serviço da inserção internacional do Brasil'. Revista Brasileira de Política Internacional (41):42-65. https://doi. org/10.1590/S0034-73291998000300004

Amorim Neto, O and J C C Rodriguez. 2016. 'O novo método histórico-comparativo e seus aportes à ciência política e à administração pública'. Revista de Administração Pública (50):1003-1027. https://doi.org/10.1590/0034-7612156950

Angell, N. 2002. A grande ilusão. São Paulo; Brasília: Imprensa Oficial do Estado; Editora Universidade de Brasília : Instituto de Pesquisa de Relações Internacionais.

Barasuol, F and A Silva, A. 2016. 'International Relations Theory in Brazil: trends and challenges in teaching and research.' Revista Brasileira de Política Internacional (59):1-20.

Beach, D and R Pedersen. 2013. Process-tracing methods: foundations and guidelines. City:Ann Arbor: University of Michigan Press.

Biersteker, T. 2009. 'The parochialism of hegemony: Challenges for "American" International Relations.' In A B Tickner and O Wæver (eds), International Relations Scholarship around the World, Worlding beyond the West. New York: Routledge.

Bilgin, P. 2008. 'Thinking past 'Western' IR?' Third World Quarterly (29):5-23. https://doi. org/10.1080/01436590701726392

Brady, H E and D Collier (eds). 2004. Rethinking social inquiry: diverse tools, shared standards. Lanham: Rowman \& Littlefield.

Brecher, M. 1999. ISA Presidential Address. International Studies Quarterly (43):213-264. https:// doi.org/10.1111/0020-8833.00119

Bull, H. 1966. 'International Theory: The Case for a Classical Approach.' World Politics (18):361-377. https://doi.org/10.2307/2009761

Carr, E H. 1989. The twenty years' crisis 1919-1939: an introduction to the study of international relations. 2. ed., repr. ed. London: Macmillan.

Casarões, G. 2019. 'The Evolution of Foreign Policy Studies: Four Perspectives' In B Ames (ed), Routledge Handbook of Brazilian Politics. New York: Routledge.

Cox, R W. 1981. 'Social Forces, States and World Orders: Beyond International Relations Theory' Millennium (10):126-155. https://doi.org/10.1177/03058298810100020501

Deutsch, K W and JD Singer. 1964. 'Multipolar Power Systems and International Stability'. World Politics (16):390-406. https://doi.org/10.2307/2009578

Dulci, T M S. 2013. Instituto Brasileiro de Relações Internacionais (IBRI)/ Revista Brasileira de Política Internacional (RBPI): desenvolvimento e integração do Brasil nas américas (1954-1992). Doutorado em História Social. São Paulo: Universidade de São Paulo. https://doi.org/10.11606/T.8.2013. tde-13092013-115630 
Editorial Scope and Policy [WWW Document], n.d. . Revista Brasileira de Política Internacional. URL https://www.scielo.br/revistas/rbpi/iinstruc.htm (accessed 4.30.20).

Eun, Y-S. 2017. 'To what extent is post-positivism 'practised' in International Relations? Evidence from China and the USA.' International Political Science Review (38): 593-607. https://doi. org/10.1177/0192512116642222

Falleti, T G and J Mahoney. 2015. 'The comparative sequential method' In J Mahoney and K Thelen (eds), Advances in Comparative-Historical Analysis. Cambridge: Cambridge University Press, pp. 211-239. https://doi.org/10.1017/CBO9781316273104.009

Faria, C A. 2011. 'O ensino e a pesquisa sobre política externa no campo das Relações Internacionais do Brasil'. Proceedings of the 3rd ENABRI 2011. São Paulo: $3^{\circ}$ Encontro Nacional ABRI.

Fonseca Júnior, G. 1998. A legitimidade e outras questões internacionais. São Paulo: Paz e Terra.

George, A L and A Bennett. 2005. Case studies and theory development in the social sciences, BCSIA studies in international security. Cambridge: MIT Press.

Goertz, G and J Mahoney. 2012. A tale of two cultures: qualitative and quantitative research in the social sciences. Princeton: Princeton University Press.

Herz, M. 2002. 'O Crescimento da Área de Relações Internacionais no Brasil.' Revista Brasileira de Política Internacional (24): 7-40.

Hyde, S D. 2007. 'The Observer Effect in International Politics: Evidence from a Natural Experiment.' World Politics (60): 37-63.

Imbens, G and D B Rubin. 2015. Causal inference for statistics, social, and biomedical sciences: an introduction. New York: Cambridge University Press.

Instructions for authors [WWW Document], n.d. . International Organization. URL https://www. cambridge.org/core/journals/international-organization/information/instructions-contributors (accessed 4.30.20a).

Instructions for authors [WWW Document], n.d. . World Politics. URL https://www.cambridge.org/ core/journals/world-politics/information/instructions-contributors (accessed 4.30.20b).

Jackson, P T and D H. 2013. 'International theory in a post-paradigmatic era: From substantive wagers to scientific ontologies.' European Journal of International Relations (19):543-565. https:// doi.org/10.1177/1354066113495482

Jørgensen, K E, A Alejandro, A Reichwein, F Rösch and H Turton. 2017. Reappraising European IR Theoretical Traditions, 1st ed. 2017. ed, Trends in European IR Theory. Cham: Palgrave Macmillan. https://doi.org/10.1007/978-3-319-58400-3

Kaplan, M A. 1966. 'The New Great Debate: Traditionalism vs. Science in International Relations.' World Politics (19): 1-20. https://doi.org/10.2307/2009840

Kristensen, P M. 2020. 'The South in "Global IR": Worlding Beyond the "Non-West" in the Case of Brazil.' International Studies Perspectives ekz029. https://doi.org/10.1093/isp/ekz029

Kristensen, P M. 2018. 'International Relations at the End: A Sociological Autopsy'. International Studies Quarterly. https://doi.org/10.1093/isq/sqy002

Kubálková, V. (ed). 2001. Foreign policy in a constructed world, International relations in a constructed world. Armonk: M.E. Sharpe,.

Lapid, Y. 1989. 'The Third Debate: On the Prospects of International Theory in a Post-Positivist Era.' International Studies Quarterly (33):235-254. 
Lichterman, P. 2017. 'Interpretive reflexivity in ethnography'. Ethnography (18):35-45. https://doi. org/10.1177/1466138115592418

Lima, M R. 2013. 'Relações Internacionais e Políticas Públicas: a contribuição da Análise de Política Externa’ In: A Política Pública Como Campo Multidisciplinar. São Paulo: Editora UNESP.

Lins, R. 2020. 'Tempo, tempo, tempo: regressão de Cox na ciência política.' Revista Política Hoje. (1):1

Lohaus, M and W Wemheuer-Vogelaar. 2020. 'Who Publishes Where? Exploring the Geographic Diversity of Global IR Journals.' International Studies Review viaa062. https://doi.org/10.1093/isr/ viaa062

Maliniak, D, A Oakes, S Peterson and M J Tierney. 2011. 'International Relations in the US Academy: International Relations in the US Academy'. International Studies Quarterly (55):437-464. https:// doi.org/10.1111/j.1468-2478.2011.00653.x

Maliniak, D, S Patterson, R Powers and M Tierney. 2017. TRIP 2017 Faculty Survey. n/a?

Mearsheimer, J and S Walt. 2013. 'Leaving theory behind: Why simplistic hypothesis testing is bad for International Relations.' European Journal of International Relations (19):427-457. https://doi. org/10.1177/1354066113494320

Mignolo, W D. 2002. 'The Geopolitics of Knowledge and the Colonial Difference.' South Atlantic Quarterly (101): 57-96. https://doi.org/10.1215/00382876-101-1-57

Montsion, J M. 2018. 'Ethnography and international relations: situating recent trends, debates and limitations from an interdisciplinary perspective.' Journal of. Chinese. Sociology. (5):9. https://doi. org/10.1186/s40711-018-0079-4

Morgan, S L and C Winship. 2007. Counterfactuals and causal inference: methods and principles for social research. New York: Cambridge University Press.

Morgenthau, H J. 1978. Politics among nations: the struggle for power and peace. New York: Knopf.

Parris, D and J Peachey. 2013. 'A Systematic Literature Review of Servant Leadership Theory in Organizational Contexts.' Journal of Business Ethics (113):337-393.

Pereira, A and Lopes, D, 2020. 'Segurança e instituições internacionais: o Brasil em perspectiva' In As Teorias e o Caso.

Rezende, F. 2017. '(Desvendando) A Dinâmica do Ajuste Inferencial nas Relações Internacionais (2000-2017).' Conexão Política (6):11-54.

Ridley, D. 2012. The Literature Review: A Step-by-Step Guide for Students, 2ed. ed. London: SAGE Publications.

Santos, N B dos and F E Fonseca. 2009. 'A pós-graduação em relações internacionais no Brasil.' Contexto Internacional (31):353-380. https://doi.org/10.1590/S0102-85292009000200005

Schwether, N D, N S De Moura and M M Melo e Silva. 2019. 'Research design in International Relations: analysis about the methodological culture of RBPI's papers (1994-2017)' Desenho de pesquisa em Relações Internacionais: análise da cultura metodológica nos artigos da RBPI (1994-2017). RMI 10, e37923. https://doi.org/10.12957/rmi.2019.37923

Scope and Policy, n.d. . Contexto Internacional. URL https://www.scielo.br/revistas/cint/iinstruc. htm (accessed 4.30.20).

Sprinz, D F and Y Wolinsky-Nahmias (eds). 2004. Models, numbers, and cases: methods for studying international relations. Ann Arbor: University of Michigan Press. 
Tickner, A. 2009. 'Latin America: Still policy dependent after all these years?' In A B Tickner and O Wæver. (eds), International Relations Scholarship around the World, Worlding beyond the West. New York: Routledge.

Tickner, A B and O Wæver. (eds). 2009. International relations scholarship around the world, Worlding beyond the West. New York: Routledge .

Vigevani, T, L F Thomaz and L A B Leite. 2016. 'Pós graduação em Relações Internacionais no Brasil: Anotações sobre sua institucionalização.' Revista Brasileira de Ciências Sociais (31):01. https://doi. org/10.17666/319104/2016

Villa, R and M C Pimenta. 2017. 'Is International Relations still an American social science discipline in Latin America?' Opinião Pública (23): 261-288. https://doi.org/10.1590/1807-01912017231261

Viotti, P R and M V Kauppi. 2012. International relations theory, 5th ed. ed. Boston: Longman.

Wæver, O. 1998. 'The Sociology of a Not So International Discipline: American and European Developments in International Relations.' International Organization (52):687-727. https://doi. org/10.1162/002081898550725

Wallerstein, I. 1997. 'Eurocentrism and its Avatars: The Dilemmas of Social Science.' Sociological Bulletin (46) 21-39. https://doi.org/10.1177/0038022919970102

Waltz, K. 1992. Man, the state and war: a theoretical analysis. Reprint. ed. New York: Columbia Univ. Press.

Wemheuer-Vogelaar, W, N J Bell, M Navarrete Morales and M J Tierney. 2016. 'The IR of the Beholder: Examining Global IR Using the 2014 TRIP Survey.' International Studies Review (18):1632. https://doi.org/10.1093/isr/viv032

Wendt, A. 1992. 'Levels of analysis vs. agents and structures: part III'. Review of International Studies (18):181-185. https://doi.org/10.1017/S0260210500118844

\section{Acknowledgements}

We thank Elia Cia Alves, Vinicius Santos, Yulieth Martínez Villalba, Kelly Meira, Florencia Lorenzo, Jessica Fernandes, and Luiz Silva for their valuable comments and substantial contribution to this article. We also thank the Coordenação de Aperfeiçoamento de Pessoal de Nível Superior (CAPES) for the funding for this research.

\section{About the authors}

Thales Carvalho is a Ph.D. candidate in Political Science at the Federal University of Minas Gerais (UFMG), and visiting graduate student at the University of California, San Diego, at the Department of Political Science. He earned a master's degree in Political Science from UFMG and a bachelor's degree in International Relations from the Pontifical Catholic University of Minas Gerais (PUC-MG). He is also a member of the International Institutions, Foreign Policy, and Political Regimes Research Network (RIPPERP). His research focuses on international security and defense policies in Latin America, especially on identifying how domestic and international variables interact to produce these policies. His research interests also include foreign policy, quantitative methods, scientometrics, 
and policy diffusion. His curriculum vitae can be found at https://tcarvalho.netlify.app/ media/cv.html. His Twitter handle is @thaleslcarvalho.

João Paulo Nicolini Gabriel is a Ph.D. candidate in Political Science at the Federal University of Minas Gerais (UFMG) and, simultaneously, at the Université Catholique de Louvain (Belgium), due to a co-tutorship agreement signed in 2021. His Ph.D. dissertation addresses macro-structural causes that drove emerging powers not to adhere to multilateral non-proliferation mechanisms during the Cold War. He earned a master's degree in International Relations from the San Tiago Dantas Postgraduate Program in International Relations (São Paulo State University - UNESP/University of Campinas UNICAMP/Pontifical Catholic University of São Paulo - PUC-SP). His research expertise is in IR theory, Indo-Pacific studies, qualitative methods, ethnic interest groups, Indian foreign policy, and comparative politics. His curriculum vitae can be found at lattes.cnpq. br/9356537757576148. His Twitter handle is @jpnicogabriel.

Dawisson Belém Lopes is a Professor of International and Comparative Politics at the Federal University of Minas Gerais (UFMG) and a research fellow of the National Council for Technological and Scientific Development (CNPq) in Brazil. He is currently the Deputy Dean for International Affairs at UFMG and has authored/edited ten books and dozens of peer-reviewed articles on topics related to Latin American politics, Brazilian foreign policy, and international institutions. Professor Lopes has previously served as visiting researcher at Germany's GIGA Hamburg, visiting Professor at the Catholic University of Louvain in Mons, Belgium, Raisina Young Fellow at India's Observer Research Foundation, and US Department of State 'SUSI Scholar' on Foreign Policy. His curriculum vitae can be found at http://lattes.cnpq.br/2002314936671237. His Twitter handle is @dbelemlopes. 


\section{"Atenção ao Hiato": Avaliando Diferenças nas Abordagens Metodológicas entre as Revistas Brasileiras e as Principais Publicações de RI}

Resumo: Este artigo analisa a produção acadêmica de RI no Brasil. O objetivo final é retratar o desenvolvimento metodológico desta disciplina, especialmente investigando se houve a incorporação dos debates mais recentes do campo. Para tanto, comparamos as ferramentas metodológicas empregadas em artigos de pesquisa publicados nas duas principais revistas nacionais (Revista Brasileira de Política Internacional e Contexto Internacional) com um par de revistas internacionais de maior impacto (International Organization e World Politics), de 2009 a 2019. Utilizando uma Revisão Sistemática da Literatura, analisamos 955 artigos. Como conclusão, constatamos que a academia brasileira de RI difere do mainstream porque (1) a maior parte dos artigos não menciona os métodos utilizados nas análises, (2) tal literatura apresenta mais métodos não e pós-positivistas e, (3) ao contrário do mainstream, métodos quantitativos são raramente utilizados no país.

Palavras-chave: metodologia; Relações Internacionais; Brasil; produção acadêmica; revisão sistemática de literatura.

Received on 23 April 2021, and approved for publication on 25 August 2021.

\section{(cc) BY-NC} https://creativecommons.org/licenses/by-nc/4.0/ 


\section{Appendix A}

\section{Criteria for classifying each article as having a qualitative, quantitative or multimethod research.}

\begin{tabular}{|c|c|c|}
\hline $\begin{array}{l}\text { TYPE OF } \\
\text { METHODOLOGY }\end{array}$ & CRITERIA & EXAMPLES \\
\hline Qualitative & $\begin{array}{l}\text { Articles that mentioned methods that require } \\
\text { small-n (a small number of observations) } \\
\text { designs to be employed. These methods } \\
\text { relate to analyses that dig deeper into cases, } \\
\text { focusing on their specificities, in order to } \\
\text { provide detailed information about facts and } \\
\text { mechanisms. }\end{array}$ & $\begin{array}{l}\text { Case Studies, Comparative Analyses, } \\
\text { Historical Analysis, Process-Tracing, } \\
\text { Discourse Analysis, Ethnography. } \\
\text { Qualitative Comparative Analysis } \\
\text { was included in this category, since } \\
\text { it is mostly related to qualitative } \\
\text { codification and analysis of cases. } \\
\text { Content analysis was included in } \\
\text { this category because, despite it } \\
\text { sometimes relate to a high number of } \\
\text { documents, we noted it often relates } \\
\text { to a small number of cases. }\end{array}$ \\
\hline Quantitative & $\begin{array}{l}\text { Articles that mentioned methods that require } \\
\text { large-n (a large number of observations) } \\
\text { designs to be employed. These methods relate } \\
\text { to analyses that often quantify information } \\
\text { and try to establish patterns to be applied to } \\
\text { a sample and, eventually, a population, using } \\
\text { statistical techniques. }\end{array}$ & $\begin{array}{l}\text { Regressions (logistic, ordinary least } \\
\text { squares, etc.), Cox Proportional } \\
\text { Hazards, Matching, Panel Data } \\
\text { Analysis, Difference-of-means, } \\
\text { Correlation Tests (Pearson, Spearman, } \\
\text { etc.), Factor Analysis, Principal } \\
\text { Component Analysis, ANOVA. }\end{array}$ \\
\hline Multi-methods & $\begin{array}{l}\text { Articles that mentioned methods included } \\
\text { in both qualitative and quantitative } \\
\text { methodologies. }\end{array}$ & \\
\hline
\end{tabular}

